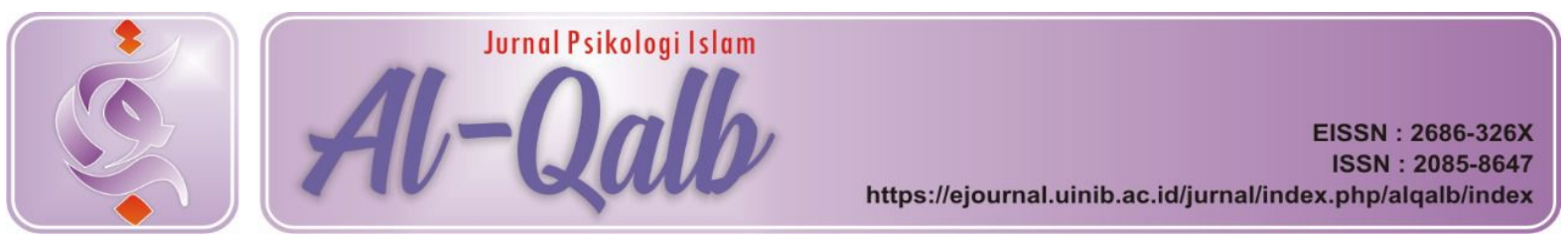

\title{
PELATIHAN KOMUNIKASI INTERPERSONAL UNTUK MENINGKATKAN KOMITMEN ORGANISASI KARYAWAN
}

Received: $25^{\text {th }}$ September 2018; Revised: $13^{\text {th }}$ October 2018; Accepted: $27^{\text {th }}$ November 2018

\section{Nira Gusfika}

UIN Imam Bonjol Padang

Email: Gusfikanira@yahoo.co.id

ABSTRACT. This study aims to determine the improvement of organizational commitment through interpersonal communication training. The hypothesis of this research is that there is a difference of organizational commitment to employees between before and after being given interpersonal communication training on experimental group, where the level of commitment of employee organization after being given interpersonal communication training is higher than the level of organizational commitment of the employees before being given interpersonal communication training. Second hypothesis, there is difference of posttest organizational commitment level between experiment group and control group, where posttest of organizational commitment in experiment group is higher than control group.

The subject of this research is 17 employees at STAI YAPPTI Balaiselasa. Characteristics of the subjects of this study are employees who have levels of organizational commitment and interpersonal communication in the category very low, low and medium. The design used was PretestPosttest Control Group, while the data was collected using organizational commitment scale then analyzed using Mann Whitney test to see the difference of score between the experimental group who were given interpersonal communication training with the control group who were not given interpersonal communication training. Furthermore, Wilcoxon test was done for see experimental group scores between before and after interpersonal communication training.

Based on Mann Whitney test results found $Z=-3.447$ $(p<0.01)$, meaning there is a difference in scores between experimental groups who were trained with control groups who were not trained. Based on Wilcoxon test results found there was a difference between organizational commitment score in the experimental group between before and after being given interpersonal communication training with $Z=-2,668$ $(p<0,01)$.

Keywords: Interpersonal Communication Training, Organizational Commitment

\section{A. PENDAHULUAN}

Perguruan tinggi merupakan lembaga pendidikan tinggi yang menghasilkan lulusan-lulusan yang ahli dalam berbagai kebutuhan masyarakat, bangsa, dan negara. Pada saat ini semakin banyak penduduk
Indonesia yang mengikuti pendidikan tinggi untuk memperoleh pendidikan yang lebih baik sehingga dapat meningkatkan harkat kehidupannya. Seiring dengan 
banyaknya permintaan akan pendidikan tinggi yang berkualitas maka masyarakat juga tentunya akan menuntut kualitas dari perguruan tinggi.

Setiap perguruan tinggi sangat membutuhkan karyawan yang memiliki rasa terikat atau komitmen yang tinggi untuk membantu organisasinya mencapai tujuan, visi dan misi secara efektif dan efisien (Stowers, 2010). Bateman dan Strasse (1984) mendefinisikan komitmen organisasi secara multidimensi, meliputi loyalitas karyawan terhadap organisasi, keinginan untuk memberikan upaya yang terbaik sebagai bagian dari organisasi, tingkat kesesuaian antara tujuan dan nilainilai organisasi dengan tujuan dan nilainilai karyawan, serta hasrat untuk mempertahankan keanggotaan dalam organisasi. Selain itu komitmen organisasi merupakan sebuah bentuk keterikatan antara karyawan dengan organisasinya (Schultz, 1998).

Sikap di atas dilanjutkan dengan adanya kemauan untuk mengerahkan usaha terbaiknya dalam bekerja yang ditandai dengan seluruh anggota bekerja sesuai dengan tanggung jawabnya masing-masing, sanggup menyelesaikan tugasnya sesuai dengan rencana maupun bekerja secara profesional demi organisasi. Karyawan yang memiliki komitmen yang tinggi juga bersedia menambah jam kerjanya untuk menyelesaikan pekerjaannya, dan ikut bertanggung jawab terhadap keberhasilan dan kegagalan organisasi serta ikut melibatkan diri untuk menyelesaikan masalah yang dihadapi organisasi. Hal ini ditandai dengan rasa nyaman yang dimiliki oleh karyawan sehingga tidak adanya keinginan untuk mencari organisasi lain dan bersedia untuk tetap bekerja hingga pensiun. Hal ini sejalan dengan pendapat Mowday, Porter \& Steers (dalam Wasti, 2003) yang menjelaskan bahwa, para anggota yang memiliki komitmen kuat terhadap organisasi merupakan bagian yang paling kecil kemungkinannya untuk keluar dari organisasi. Sebaliknya, anggota dengan komitmen organisasi yang rendah merupakan bagian yang sangat rentan untuk mudah melakukan proses keluar masuk.

Berdasarkan penjelasan mengenai komitmen organisasi dari berbagai teori di atas, maka dapat diambil sebuah kesimpulan bahwa komitmen karyawan dalam organisasi sangatlah penting. Komitmen yang rendah merupakan salah satu hal yang menyebabkan seseorang mudah meninggalkan organisasi seperti pengunduran diri dari perusahaan tempat bekerja. Padahal dari sisi organisasi sendiri, kinerja organisasi sangat bergantung pada komitmen anggotanya.

Berdasarkan hasil wawancara dengan ketua STAI YAPTTI Balaiselasa pada tanggal 19 Juni 2017, menjelaskan bahwa karyawan pada level staf dalam melaksanakan tugas seringkali saling melempar tanggung jawab dan saling menyalahkan jika terjadi permasalahan. Selain itu banyak karyawan yang tidak profesional dalam menggunakan waktu seperti datang terlambat, tidak segera melakukan pekerjaan saat masuk jam kerja, pulang lebih awal tanpa ijin, terlambat dalam membuat berbagai laporan, tidak bersedia hadir saat diadakan rapat dan seringkali karyawan bekerja tanpa mengikuti standar operasional prosedur yang telah dibuat.

Selain itu pada tanggal 19 Juni 2017, PUKET I bidang akademik juga menjelaskan, terdapat 2 orang karyawan yang mengundurkan diri pada rentang Januari hingga Juni, dengan alasan merasa tidak dilibatkan dalam pengambilan dari setiap keputusan di organisai, sehingga menimbulkan perasaan tidak dihargai dan tidak berguna, namun menurut penjelasan PUKET I, pada setiap rapat diadakan karyawan ini selalu diberikan surat undangan namun mereka tidak pernah hadir di dalamnya, hal ini menyebabkan hal-hal yang dibahas pada rapat tidak dapat mereka dipahami dengan jelas.

Desler (1994) menjelaskan komitmen organisasi karyawan di tempat kerja sangat dipengaruhi oleh beberapa hal 
yaitu, dipengaruhi oleh nilai-nilai kemanusiaan dan ini sebagai prioritas utama yang harus dipenuhi perusahaan. Selanjutnya komitmen juga dipengaruhi oleh komunikasi dua arah yang komprehensif. Komitmen dibangun atas dasar kepercayaan dan kepercayaan membutuhkan komunikasi dua arah. Beberapa organisasi bahkan berusaha mengembangkan beberapa program yang menjamin berlangsungnya komunikasi tersebut. Berdasarkan pendapat Desler di atas, diketahui pentingnya komunikasi dua arah (komunikasi interpersonal) dalam membangun komitmen karyawan.

Berdasarkan uraian di atas serta fakta-fakta mengenai rendahnya komitmen organisasi karyawan, maka penelitian ini akan mengkaji lebih dalam mengenai pelatihan komunikasi interpersonal sebagai salah satu cara untuk meningkatkan komitmen organisasi pada karyawan level staf di STAI YAPPTI Balaiselasa.

\section{B. TINJAUAN TEORI}

1. Definisi Komitmen Organisasi

Komitmen organisasi hingga saat ini masih menjadi pembicaraan relevan dan berperan sentral dalam penelitianpenelitian perilaku organisasi, karena pengelolaan sumber daya manusia perlu memperhatikan komitmen karyawannya. Komitmen karyawan yang tinggi akan sangat berpengaruh pada pencapaian tujuan organisasi. Komitmen organisasi pertama kali di definisikan oleh Becker (1960 dalam Rhoades dan Eisenberger 2002), sebagai kecenderungan seseorang untuk terikat dalam aktivitas organisasi secara berkelanjutan yang berdasarkan pada penghargaan yang diberikan dan dihubungkan dengan ketidakberlanjutan individu dalam aktivitas organisasi.

Berdasarkan definisi teoritis di atas maka dapat disimpulkan bahwa komitmen organisasi merupakan wujud dari tingkat penerimaan seseorang terhadap tujuan organisasi sehingga menimbulkan keterikatan secara psikologis antara karyawan dengan organisasinya.
2. Dimensi Komitmen Organisasi

Mowday, Porter \& Steers (dalam Yousef, 2003) secara rinci menjelaskan dimensi komitmen organisasi sebagai berikut:

a) Sikap seorang anggota dalam mengidentifikasikan diri terhadap nilainilai dan tujuan organisasi, yang menggambarkan keterikatan terhadap ideologi yang dibuat dan telah ditentukan oleh organisasi.

b) Adanya kemauan untuk mengerahkan usaha terbaiknya dalam bekerja. Ditandai dengan seluruh anggota bekerja sesuai dengan tanggung jawabnya masing-masing. c) Adanya keinginan untuk tetap menjadi anggota organisasi yang adalah merupakan faktor kebanggaan dan loyalitas yang dimiliki seseorang secara berkesinambungan.

3. Pelatihan Komunikasi Interpersonal

Pelatihan komunikasi interpersonal adalah salah satu program pelatihan yang disusun dengan tujuan mengasah keterampilan seseorang dalam melakukan komunikasi interpersonal sehingga seseorang mempunyai kecakapan sosial dan kecakapan behavioral (Suseno, 2009).

Pelatihan khususnya pelatihan komunikasi interpersonal dalam penelitian ini merupakan metode yang dipilih dan dirancang oleh peneliti guna meningkatkan komunikasi interpersonal karyawan STAI YAPTTI Balaiselasa. Pelatihan dikembangkan berdasarkan aspek komunikasi interpersonal yaitu, menimbulkan rasa keterbukaan, empati, sikap positif dan kesetaraan (Devito, 2006). 4. Pengaruh Pelatian Komunikasi Interpersonal Terhadap Komitmen Organisasi

Pelatihan khususnya pelatihan komunikasi interpersonal merupakan metode yang dipilih dan dirancang oleh peneliti guna meningkatkan komunikasi interpersonal karyawan STAI YAPTTI Balaiselasa dengan mengembangkan beberapa aspek komunikasi interpersonal yaitu, menimbulkan rasa keterbukaan, empati, sikap positif, saling mendukung 
dan kesetaraan di antara karyawan (Devito, 2006).

Keterbukaan didefinisikan sebagai kemampuan untuk membuka atau mengungkapkan unsur-unsur kepribadian diri sendiri melalui komunikasi. Kualitas keterbukaan mengacu pada sedikitnya tiga aspek dari komunikasi interpersonal. Pertama, komunikator interpersonal yang efektif harus terbuka kepada orang yang diajaknya berinteraksi, harus ada kesediaan untuk membuka diri mengungkapkan informasi yang biasanya disembunyikan, asalkan pengungkapan diri ini patut. Aspek keterbukaan yang kedua mengacu kepada kesediaan komunikator untuk bereaksi secara jujur terhadap stimulus yang datang. Aspek ketiga menyangkut kepemilikan perasaan dan pikiran dan bertanggung jawan terhadap apa yang telah disampaikan.

Empati merupakan kemampuan seseorang untuk mengetahui dan dapat merasakan apa yang sedang dialami orang lain pada suatu saat tertentu, dari sudut pandang orang lain itu. Melalui kacamata orang lain itu, rasa empati dapat diperlihatkan seseorang dari keterlibatan aktif saat mendengarkan orang lain bicara dan memiliki ekspresi wajah dan gerakgerik yang sesuai.

Sikap mendukung merupakan sikap yang ditunjukan dengan tidak memberikan penilaian terhadap penjelasan orang lain, menerima perbedaan dan bersikap fleksibel. Sikap positif dalam komunikasi interpersonal dilakukan dengan dua menyatakan sikap positif pada lawan bicara dan secara positif mendorong orang yang menjadi teman kita berinteraksi. Sedangkan Kesetaraan merupakan wujud dari pengakuan secara diam-diam bahwa kedua pihak sama-sama bernilai dan berharga, dan bahwa masing-masing pihak mempunyai sesuatu yang penting untuk disumbangkan.

Aspek-aspek komunikasi interpersonal di atas berimplikasi pada perilaku individu dalam proses komunikasi dalam berinteraksi dengan individu lain dalam organisasi. Hal ini akan mencipatakan dukungan sosial sehingga membuat individu merasa lebih nyaman pada sesama anggota organisasinya, sehingga komitmen terhadap organisasinya (Novianti, 2008). Hal ini juga sejalan dengan penelitian Harjana (2007), yang menjelaskan bahwa iklim organisasi yang nyaman menjadi acuan dan pedoman untuk pembuatan keputusan, untuk mengerjakan tugas secara efektif dan membangun tekad dan komitmen organisasi. Selain itu iklin yang nyaman membuat karyawan termotivasi dalam mengejar peluang organisasi dengan penuh semangat, menolong sesama karyawan, menyelesaikan tugas secara kreatif dan penuh dengan ide-ide untuk pembaharuan dan peningkatan kinerja karyawan dalam organisasi.

\section{HIPOTESIS}

Hipotesis yang digunakan dalam penelitian ini adalah, "Terdapat perbedaan komitmen organisasi pada karyawan STAI YAPTTI Balaiselasa antara sebelum dengan sesudah diberikan pelatihan komunikasi interpersonal pada kelompok eksperimen. "Terdapat perbedaan posttest komitmen organisasi antara kelompok eksperimen dengan kelompok kontrol, dimana komitmen organisasi pada kelompok eksperimen lebih tinggi dibanding kelompok kontrol”.

\section{METODE}

1. Identifikasi Variabel Penelitian Terdapat dua variabel yang akan diukur dalam penelitian ini, yaitu:

a. Variabel independen, Variabel independen dalam penelitian ini adalah pelatihan komunikasi interpersonal.

b. Variabel dependen, Variabel dependen dalam penelitian ini adalah komitmen organisasi.

2. Subjek Penelitian

Subjek penelitian ini adalah seluruh karyawan level staf di STAI YAPTTI Balaiselasa yang terdaftar sebagai 
karyawan yang memiliki kontrak kerja, berjumlah 17 orang.

3. Desain Penelitian

Jenis penelitian yang digunakan dalam penelitian ini merupakan penelitian eksperimen. Menurut Arikunto (2006), metode penelitian eksperimen adalah salah satu cara untuk mencari hubungan sebab akibat antara dua faktor yang sengaja ditimbulkan oleh peneliti dengan mengeliminasi atau mengurangi faktor-faktor lain yang mengganggu.

Rancangan dalam penelitian ini adalah dengan menggunakan desain eksperimen, yaitu Pre-Test Post-Test Contol Group Design.

4. Metode pengumpulan data

Data dalam penelitian ini dikumpulkan dengan menggunakan skala komitmen organisasi dan skala komunikasi interpersonal. Azwar (2006) menjelaskan bahwa skala dapat dicirikan sebagai stimulasi yang berupa pernyataan.

Sebelum digunakan untuk penelitian, skala komitmen organisasi dan skala komunikasi interpersonal ini terlebih dahulu akan di ujicobakan, hal ini bertujuan untuk menguji validitas dan reliabilitas alat ukur tersebut. Uji coba alat ukur ini akan dilakukan kepada 18 karyawan STAI YAPTTI Painan.

Berdasarkan hasil uji coba skala komitmen organisasi, maka diketahui validitas skor tiap-tiap aitem bergerak antara 0,327 hingga 0,873, sedangkan hasil uji reliabilitas seluruh aspek setelah ujicoba adalah 0,925. Berdasarkan hasil uji coba skala komunikasi interpersonal, maka diketahui validitas skor tiap-tiap aitem bergerak antara 0,396 hingga 0,963, sedangkan hasil uji reliabilitas seluruh aspek adalah 0,982 .

\section{E. HASIL DAN PEMBAHASAN}

Terdapat dua uji hipotesis dalam pelitian ini, yang pertama bertujuan untuk melihat apakah terdapat perbedaan komitmen organisasi antara kelompok eksperimen yang diberi pelatihan komunikasi interpersonal dengan kelompok kontrol yang tidak diberi pelatihan, uji hipotesis ini menggunakan uji Mann Whitney.

Adapun hasil dari uji Mann Whitney menunjukkan nilai $Z=-3,477$ pada $p<0,01$. Hal ini berarti ada perbedaan komitmen organisasi yang signifikan antara kelompok eksperimen dan kelompok kontrol. Perbedaan tersebut dapat dilihat pada ranking kelompok eksperimen (KE) 13,00 dan kelompok kontrol (KK) 4,50. Berdasarkan hasil tabel di atas maka dapat di ambil kesimpulan, bahwa skor komitmen organisasi pada kelompok eksperimen (KE) lebih tinggi dibanding skor komitmen organisasi pada kelompok kontrol (KK). Selisih perbedaan rata-rata tersebut adalah 8,5, dengan demikian hipotesis pertama diterima.

Sedangkan hipotesis yang kedua bertujuan untuk melihat perbedaan komitmen organisasi antara sebelum dengan sesudah diberikan pelatihan komunikasi interpersonal pada kelompok eksperimen (KE), uji hipotesis ini menggunakan uji Wilcoxon. Hasil statistik dari uji Wilcoxon, diperoleh nilai $\mathrm{Z}=$ 2,688 pada $p<0,01$. Artinya ada perbedaan tingkat komitmen organisasi karyawan staf STAI YAPPTI Balaiselasa antara sebelum diberikan pelatihan komunikasi interpersonal dengan setelah diberikan pelatihan komunikasi interpersonal, dengan demikian hipotesis kedua diterima.

Berdasarkan penjelasan dari hasil penelitian, diketahui bahwa pelatihan komunikasi interpersonal dapat meningkatkan komitmen organisasi karyawan staf STAI YAPPTI Balaiselasa. Peningkatan ini tidak hanya didapat dari analisis statistik saja, namun juga diperoleh dari evaluasi-evaluasi yang peneliti lakukan. Selain itu penelitian ini juga didukung oleh penelitian lainnya yang menunjukkan bahwa pelatihan komunikasi interpersonal efektif untuk meningkatkan komitmen organisasi pada karyawan. 
Aspek-aspek

komunikasi interpersonal seperti keterbukaan, empati, sikap positif dan saling mendukung serta membangun sikap kesetaraan berimplikasi pada perilaku individu dalam proses komunikasi dalam berinteraksi dengan individu lain dalam organisasi. Hal ini akan mencipatakan dukungan sosial sehingga membuat individu merasa lebih nyaman pada sesama anggota organisasinya, sehingga komitmen terhadap organisasinya menjadi lebih tinggi (Novianti, 2008). Hal ini juga sejalan dengan penelitian Harjana (2007), yang menjelaskan bahwa iklim organisasi yang nyaman menjadi acuan dan pedoman untuk pembuatan keputusan, untuk mengerjakan tugas secara efektif dan membangun tekad dan komitmen organisasi. Selain itu iklim yang nyaman membuat karyawan termotivasi dalam mengejar peluang organisasi dengan penuh semangat, menolong sesama karyawan, menyelesaikan tugas secara kreatif dan penuh dengan ide-ide untuk pembaharuan dan peningkatan kinerja karyawan dalam organisasi.

Alur perubahan perilaku yang terjadi pada penelitian ini diawali dengan cara memberikan materi-materi tentang komunikasi interpersonal. Dengan memberikan materi-materi tentang komunikasi interpersonal akan meningkatkan pengetahuan karyawan tentang cara berkomunikasi interpersonal dengan rekan di dunia kerja. Selanjutnya dengan adanya pengetahuan akan menimbulkan keyakinan bahwa komunikasi interpersonal dengan rekan dalam bekerja harus dilakukan dengan benar, jika tidak tentu akan menimbulkan banyak kesalah pahaman dalam pelaksanaan tugas, dan terjadi konflikkonflik sehingga menimbulkan ketidaknyamanan dalam bekerja.

\section{F. SIMPULAN DAN SARAN}

1. Simpulan

Dapat disimpulkan bahwa terdapat perbedaan nilai posttest komitmen organisasi pada Kelompok eksperimen dengan kelompok kontrol dimana kelompok eksperimen memiliki tingkat komitmen organisasi yang lebih tinggi dari pada kelompok kontrol.

Selain itu juga terdapat perbedaan perilaku komitmen organisasi pada kelompok eksperimen antara sebelum dengan sesudah diberikan pelatihan komunikasi interpersonal, dimana tingkat komitmen organisasi setelah diberikan pelatihan lebih tinggi dibanding sebelum diberikan pelatihan komunikasi interpersonal.

2. Saran

a. Saran untuk organisasi

Pelatihan komunikasi interpersonal dalam penelitian ini terbukti mampu meningkatkan komitmen organisasi pada karyawan di STAI YAPPTI Balaiselasa.

b. Saran untuk penelitian selanjutnya
1) dapat mempertimbangkan pemberian perlakuan placebo (perlakuan yang sifatnya netral) kepada kelompok kontrol.
2) diharapkan mempertimbang-kan waktu penyelengaraan pelatihan.

\section{DAFTAR KEPUSTAKAAN}

Allen, N. J. \& Meyer, J. P. (1990). The measurement and antecedents of affective continuance and notmative commitment to organization. Journal of Occcupational Psychloghy, 63, 118.

Arikunto, Suharsimi. (2010). Prosedur penelitian suatu pendekatan praktek. Jakarta: Rineka Cipta.

Azwar, S. (2006). Reliabilitas dan validitas. Yogyakarta: Pustaka Pelajar.

Azwar, S. (2010). Penyusunan skala psikologi. Yogyakarta: Pustaka Pelajar. 
Azwar, S. (2016). Metodologi penelitian. Yogyakarta: Pustaka Pelajar.

Berlina. (2014). Pelatihan komunikasi interpersonal untuk meningkatkan komitmen organisasi karyawan PT. Cahaya Fortuna Sejati Yogyakarta. Tesis (Tidak Dipublikasi-kan). Yogyakarta: Fakultas Psikologi Universitas Gadjah Mada Yogyakarta.

Budyatna. (2015). Teori komunikasi antar pribadi. Jakarta: Kencan Prenada Media Group.

Cangara. (2005). Pengantar ilmu komunikasi. Jakarta: PT. Raja Grafindo.

Daft, R.L. (2003). Manajemen. Jilid 2. Jakarta: Penerbit Erlangga.

De Varies \& Treacy-Flofent. (2002). Creating high commitment organizations. Organiza-tional Dynamics, 30 (4), 295-309.

Dessler. (1994). Managing organization in era of change. Florida: The Dryden Press.

Devito, A.J. (1997). Komunikasi antar manusia. Jakarta: PT. Raja Grafindo Persada.

Devito, A.J. (2011). Komunikasi antar manusia: Edisi kelima (terjemah).

Pamulang: Ka-risma Publishing Gruop.

Dunham, R.B., Grube, J.A., \& Castaneda, M.B. (1994). Organizational Commit-ment: the utility of an integrative definition. Journal of Applied Psy-chology, 79, 370-380.

Eky, D.P. (2016). Modul pelatiahan komunikasi interpersonal. Modul pelatihan (Tidak

Dipublikasikan). Yogyakar-ta: Fakultas Psikologi Universitas Islam Indonesia.
Enjang. AS. (2009). Komunikasi konseling. Bandung: Nuasa.

Farhan. (2016). Hubungan antara komunikasi interpersonal dengan komitmen organisasi pada karyawan dinas pendidikan Yogyakarta. Tesis (Tidak Dipublikasikan). Yogya-karta: Fakultas Psikologi Universitas Gadjah Mada Yogyakarta.

Goldstein, I.L. \& Ford. J.K. (2002). Training in organizations: 4 edition. Belmont,CA: Wadsworth.

Harjana. (2007). Iklim komunikasi keorganisasian. Jurnal Komunikasi, 4(2), 167-177.

Hartley, Peter. (1999). Interpersonal communication: Secon edition. Rodlage.

Ingarianti, T.M. (2005). Pengembangan alat ukur komitmen organisasi. Journal RAP, 6 (1), 20-30.

Iqhsanul. (2011). Pengaruh komunikasi interpersonal terhadap komitmen organisasi. Tesis (Tidak Dipublikasikan). Bandung: Universitas Kristen Maranatha.

Ivancevich, Konopaske, J.M.\& Matteson. (2007). Perilaku dan management organi-sasi: edisi ketujuh. Terjemah Gina Gania. Jakarta: Eirlangga.

Johlke \& Duhan. (2002). Antecendent to boundary-spanner. Perceived organizational support. Journal of Managerial Psychology, 166128.

Latifah. (2016). Hubungan antara kepuasan komunikasi dengan komitmen organisasi pada karyawan rumah sakit Muhammadiyah Yogyakarta. Tesis (Tidak Dipublikasikan). Yogya-karta: Universitas Gadjah Mada Yogyakarta. 
Latipun. (2008). Psikologi eksperimen. Malang: Universitas Muhammadiyah Malang.

Leslie, Rae. (2005). Using evaluation in training and development. Jakarta: PT. Gramedia.

Lufri. (2005). Metodologi penelitian bahan ajar. Padang: UNP Press.

Luthans, F. (2002). Organizational behavior. Edisi Ke-9. New York: McGraw-Hill.

Mastuti, Winda. (2009). Pengaruh pelatihan komunikasi interpersonal terhadap komitmen organisasi pada karyawan PG. Waringin Anom Situbondo. Skripsi (Tidak Dipublikasikan). Malang: Universitas Negeri Malang

Mathieu, J.E \& Zajac, D.M. (1990). A review and meta-analysis of the antecedents, corre-lates, and consequences of organizational commitment. Psychological Bulletin, 108, 171-188.

Mayer, J.P. \& Allen, N.J. (2004). TCM Employee Commitment Survey Academic Users Guide. University of Western Ontario.

Mayer, J.P. \& Herscovitch. (2001). Commitment in the workplace: Toward a general model. Human Resaurce Management Review, 299-326.

Mayer, J.P. \& Allen, J.N. (1997). Commitment In Workplace: Theory, Research And Application. Sage Publication.

Mohammad. S. (2009). Komunikasi internasional perpektif jurnalistik. Bandung: Simbiosa Rekatama Media

Mowday, R. T,. Steers, R. M., \& Porter, L. W. (1979). The measurement of organizational commitment. Journal of Vocational Beahvior, 14(2), 224 247.

Mowday, R.T. (1982). Employeeorganization linkages: The psychology of commitment, absenteeism, and turnover. New York: Academic Press.

Muhammad, Arni. (2004). Komunikasi organisasi. Jakarta: Bumi Aksara.

Novianti. (2008). Studi kasus iklim pengaruh organisasi, komunikasi dan komitmen terhadap perilaku individu dosen negeri di Banjarmasin. Polibis Jurnal Ekonomi dan Bisnis, $6(2), 88-90$

Nurjaman. K. (2012). Komunikasi \& public relations. Bandung: Pustaka Setia.

Prasetyo. (2008). Metode penelitian kuantitatif: teori dan aplikasi. Jakarta: PT. Raja Grafindo Persada.

Priyanto, Dwi. (2008). Mandiri belajar SPSS. Yogyakarta: Mediakom.

Redding, W. Charles. \& Sanborn, A.G. (1964). Business and industrial communication: a source book. New york: Harper \& Row.

Rhoad, L. \& Eisenberger, R. (2002). Perceived organizational support: A review of literatur. Journal Of Applied Psychology. 87, 598-714.

Riswandi. (2009). Ilmu komunikasi. Jakarta: Graha Ilmu.

Rivai, F. (2005). Manajemen sumber daya manusia untuk perusahaan: dari teori ke praktek. Jakarta: Murai Kencana.

Robbins, S.P. (1996). Organization behavior. concepts, controversies, applications. Edisi ke 7. New Jersey: Prentice Hall. 
Robbins, S.P. (2008). Perilaku organisasi (Vol 1-2). Jakarta: Salemba Empat.

Schultz, P.D (1998). An introduction to industrial and organizational psychology (6th ed). New York: Mc. Millan Publishing Company.

Smither, R.D. (1997). The psychology of work and human performance. Edisike3. New York: Longman.

Sopiah. (2008). Perilaku organisasi. Yogyakarta: Andi.

Steers, R.M., \& Porter, L. W. (1983). Motivation and work behavior. Edisi $K e-3$. New York: McGraw Hill Book Company.

Steers, R.M. (1977). Antecedents and outcomes of organizational commitment. Administrative Science Quarterly, 22, 46-56.

Stower, S. (2010). Perceived organizational support and organizational commitment in the united state army reserve. Proquest Dissertation an Thesis. n/a.

Sugiyono. (2011). Metode penelitian kuantitatif, kualitatif dan $R \& D$. Bandung: IKAPI.

Sugiyono. (2015). Statistika untuk penelitian. Bandung: Alfabeta.
Suseno. (2009). Pengaruh pelatihan komunikasi interpersonal terhadap efikasi diri sebagai pelatih pada mahasiswa. Jurnal Intervensi Psikologi, 1 (1), 99-100

Wasti. (2003). Organizational commitment, turnover intentions and the influence of cultural values. Journal of Occupational and Organizational Psychology, 76 (3), 303-321.

Wayne, P.R. \& Faules, D. (1998). Komunikasi organisasi: strategi meningkatkan kinerja perusahaan. Bandung: Rosda Karya.

Widjaja. (2010). Komunikasi dan hubungan masyarakat. Jakarta: PT. Bumi Aksara.

Widoyoko. (2012). Teknik penyusunan instrumen penelitian. Yogyakarta: Pustaka Pelajar.

Yoon, J. \& Thye S.R. (2002). "A dual process models of organizational commitment job satisfaction and organizational support. Work \& uccupation, 29, 97-124.

Yousef, D.A. (2003). Organizational commitment: Testing two theories. Industrial Re-lation, 38(2), 319-343. 